\title{
The reurbanisation concept and its utility for contemporary research on post-socialist cities: The case of the Czech Republic
}

\author{
Martin OUŘEDNÍČEK a*, Martin ŠIMON a, Martina KOPEČNÁa
}

\begin{abstract}
The concept of reurbanisation is discussed in this article from theoretical and methodological perspectives. Reurbanisation has been defined as one of the stages of urban development recently, but it is also tied to processes of gentrification, or perceived as a policy aimed at the revitalisation of inner cities. The main objective of this contribution is to discuss three principal and different perspectives of reurbanisation: firstly, reurbanisation as defined on the macro-scale of settlement system development; secondly, the concept as elaborated at the micro-scale of the transformation of inner cities; and, thirdly, reurbanisation viewed as a specific urban policy at the local government scale of analysis. The authors' singular understanding of the reurbanisation process - as suburban-to-urban migration - is then presented as an alternative conceptualization of reurbanisation. This paper presents and evaluates the use of the reurbanisation concept in research on residential environments in current conditions in the Czech Republic and relates it to the broader domain of research on post-socialist cities.
\end{abstract}

Keywords: reurbanisation, metropolitan regions, migration, post-socialist cities, Czech Republic

\section{Introduction}

In contemporary urban research, there is a need to investigate reurbanisation as a process that may have a marked effect on residential environments in metropolitan regions. Given the fact that there is no consistent definition of reurbanisation (Kabisch, Haase, Haase, 2010), the term is used relatively loosely for labelling manifold urban processes - such as urban renaissance, urban resurgence, back-to-the-city movement, etc. (Glatter and Siedhoff, 2008). Reurbanisation is understood in a variety of ways, reflecting the history of a particular settlement system as well as different scholarly traditions in the regions under study.

In population geography, reurbanisation is connected with the so-called stages of urban development, where it is defined as the fourth stage in the development of a settlement system or of separate metropolitan areas (van den Berg et al., 1982; Cheshire and Hay, 1989; Ouředníček, 2000). Reurbanisation is thus understood as the quantitative growth of population in the core cities of metropolitan areas (van den Berg et al., 1982). Although this simplified model of urban development has been repeatedly criticised (Champion, 2001) or advanced (Geyer and Kontuly, 1996), the terminology it established has been retained as a tool for the description of urban system development. One of the critiques pointed out that reurbanisation is not a stage of urban development per se, but it is only a trend in migration patterns in an already urbanised settlement system and society (Champion, 2001), notwithstanding the impact of such migration in urban spaces.

In urban studies, reurbanisation is often seen as a distinctive qualitative change in local population structures, particularly in the inner neighbourhoods of cities (Haase et al., 2003; Hyra, 2015). It is often linked with urban renewal (Bernt, 2009; Grabkowska, 2015; Haase and Rink, 2015), middle class housing change (Millard-Ball, 2002; Bridge, 2006), and with the process of gentrification (Smith, 1996). Population change in inner cities might be driven by a whole array of inputs, ranging from rural-to-urban migration, suburban-to-urban migration, inner city population redistribution, or many other factors related to demographic change (Haase et al., 2011) or shifts in household and economy structure (Buzar et al., 2007; Hutton, 2004). Reurbanisation research is thus a relatively complex issue, balancing diverse empirical and theoretical approaches. In compliance with the current research situation, the principal goal of this article is to clarify the theoretical concept of reurbanisation as a specific process of urban development and to evaluate its potential influence on the socio-spatial structures of metropolitan areas in the Czech Republic. The findings could have a broader validity in post-socialist cities in general. The specific target of this article is an operationalization of the reurbanisation concept as a process of return migration of suburbanites back to the city.

The concept of reurbanisation is particularly relevant in contemporary post-socialist cities which, on the one hand, share certain common socialist urbanisation experiences (Szelényi, 1984), but on the other hand, differ significantly in their overall urban histories and current levels of urbanisation in the society (Musil, 1993, 2005). Population deconcentration and decentralisation in post-socialist countries is mostly expressed as suburbanisation, and it occurred later and to lesser extent than in western cities. The population redistribution occurred under conditions where many countries dealt with demographic change, such as population ageing, low fertility levels, an overall population decrease, and also with population losses from migration

\footnotetext{
a Urban and Regional Laboratory, Department of Social Geography and Regional Development, Faculty of Science, Charles University in Prague, Czech Republic (*corresponding author: M. Ouředníček, e-mail: slamak@natur.cuni.cz)
} 
abroad (Lesthaeghe and Willems, 1999; Gerőházi et al., 2011; Botev, 2012; DEMIFER, 2013). Current research on the dynamics of population decentralisation might therefore be challenged and revised in the near future. The possible increasing trend of reurbanisation can be seen either as a growing preference for an urban way of life, but also as an economic calculation optimizing previous residential choices. Capital cities are in an exceptional position in comparison with second-order and smaller cities, which more often share population decrease or reurbanisation trajectories in Europe (Turok and Mykhnenko, 2007).

In this article, interpretations of the reurbanisation process from various authors are reviewed, primarily within the framework of post-socialist discourse. Over the last thirty years, the term reurbanisation began to appear more frequently in both theoretical concepts and empirical research. The different approaches to the assessment of reurbanisation can be divided into three broad groups (cf. Rérat, 2012): firstly, an approach that recognises the process as one of the stages of urban development, where reurbanisation is perceived at a macro level as a process of the quantitative change in the whole settlement system; secondly, the researcher can define reurbanisation as a process that transforms a local social environment, especially in inner cities; and thirdly, the approach in which specific understandings of reurbanisation as a policy is examined. Apart from the literature review of the three different reurbanisation approaches, we advance our own operationalisation of the term, illustrate it with examples from the Czech Republic, and discuss the relevance of the concept for contemporary research on post-socialist cities.

\section{Reurbanisation as a stage of urban development: Description and criticism}

The 'stages of urban development' theory (SUD) can be seen as a distinct paradigm of settlement geography in the last thirty years or so (Champion, 2001; Ouředníček, 2000). The core ideas of SUD were independently developed in the framework of CURB ${ }^{1}$ research (van den Berg et al., 1982) and by British authors (Hall and Hay, 1980; Cheshire and Hay, 1989; Cheshire, 1995). According to van den Berg et al. (1982), reurbanisation is a phase of the urbanisation process which marks an end to a decentralisation period and a return towards concentration. The processes of decentralisation and disurbanisation (counterurbanisation) 'cause' a succession of problems in society and economy. Several studies have illustrated that population outflows outside city boundaries have negative impacts on municipal budgets and the provision of services of general interest to inhabitants and city users (Lais and Penker, 2012). The costs of public services delivery and population change are statistically related, although innovative changes in service provision might reduce the fiscal burdens (Baron et al., 2014).

Van den Berg et al. have argued that such decreasedriven problems can be mitigated by a reversal of population development and by a transition to reurbanisation. The shift back to population concentration is driven primarily by the initiatives of municipal authorities and possibly central government, through targeted programs aimed at urban renewal via housing stock investment and overall infrastructure improvement. In this stage of urban development, the decline in the city's population should slow initially in central areas and gradually in its outlying areas as well. The reurbanisation stage means a restoration of the concentration process, after which the whole urbanisation process begins again as a new cycle of development (van den Berg et al., 1982).

Perceiving reurbanisation as a stage of the urbanisation process requires caution from at least three points of view. Firstly, reurbanisation occurs in already urbanised settlement systems and societies, and therefore it is qualitatively different from previous urbanisation processes, which contribute not only to qualitative but also to quantitative changes in a society. Reurbanisation as migration from a suburban zone back to a city centre results, for instance, in population density growth in a city centre or in the revival of some declining parts of a city. It is more urban revitalisation or local regeneration of an already urbanized environment than urbanisation processes in a broad sense. It is also reasonable, however, to argue that reurbanisation has a fundamental influence on the regeneration or revitalisation of inner cities. Reurbanisation is utilized in urban policy via planning tools that seek to limit commercialisation and the de-population of inner city areas and thus to revitalise residential functions or even to substitute the original nonresidential functions (Piro and Ganser, 2012). Secondly, it became obvious that reurbanisation is not comparable - in terms of the size of migration movements and the ability to structure spatial patterns of metropolitan areas - with previous stages of urban development (Champion, 2001). Notwithstanding, reurbanisation can be considered a logical continuation as the fourth phase (stage) in the development of cities, and as a response to de-concentration tendencies in settlement system (Rérat, 2012). Thirdly, it has been found that all constituent processes of SUD (urbanisation, suburbanisation, counterurbanisation, and reurbanisation) do not appear as sequential, internally-connected stages in urban development, as in the model. In fact, they are mutually related processes that depend on the size of the social and demographic groups preferring a given residential environment, and on the context of economic progress in a society (notably purchasing power, housing policy and the real estate market) (Ouředníček, 2000).

\section{Reurbanisation as a micro-regional process}

Reurbanisation as a process transforming local residential environments on a micro-regional level can be defined as one of the city-shaping processes, essentially affecting the overall urban fabric in both its physical appearance and its social structure. Reurbanisation on a local level is mainly understood as a process of the re-settlement of central city areas (Ogden and Hall, 2000). Population change in central city areas is influenced by many factors, such as the growth of the service economy, an increasing preference for an urban way of life, and also with the renovation of historical areas of the city (Ogden and Hall, 2000). Marked changes in central city areas can be seen in many European cities today (Cassiers and Kesteloot, 2012). Haase et al. (2010) define reurbanisation broadly as a process of populating and diversifying the inner city with a variety of residential groups of different ages and socio-economic backgrounds. At present, the perception of the reurbanisation process as

\footnotetext{
${ }^{1}$ The Cost of Urban Growth; For the evaluation of city development in Europe, the so-called FUR (Functional Urban Region) was used, which makes it possible to compare the relation between population growth of a city and its hinterland (Ouředníček, 2000).
} 
a movement 'back to the city' is seen by Haase et al. (2010) rather as a shift in housing preferences than the actual return of residents from suburbia back into city.

Reurbanisation is thus seen as an ample term for various inner city population changes, which is in contrast with the migration-based definition of reurbanisation. In fact, the broad definition of reurbanisation encompasses and includes migration-based definitions, which poses a few key questions for further discussion. Does reurbanisation occur in shrinking, in stagnating, or in growing cities? In what way(s) should reurbanisation be operationalized and measured in empirical research (Glatter and Siedhoff, 2008)? To what extent is reurbanisation, as inner city population change, related to other urban processes also shaping inner cities, such as commercialisation, regeneration, marginalisation, gentrification, or incumbent upgrading?

Distinguishing between reurbanisation and gentrification concepts is complicated, particularly because it is difficult to specify the influence of wider social, economic and political changes (Atkinson, 2003). For instance, Allen and Blandy (2004) assert that positive aspects of reurbanisation include the improvement of the social environment of inner city localities due to the influx of the middle and upper classes. In a similar manner, Lever (1993) suggests that repeated colonisations of central city areas in the course of reurbanisation occur mostly in the case of inhabitants with higher incomes and residential groups preferring an urban way of life in the inner city. According to Buzar et al. (2007), however, and also to Kabish, Haase and Haase (2010), reurbanisation has an impact on the entire inner city and it represents the mobility of a wider population spectrum.

In our opinion, the gentrification process - unlike reurbanisation - affects only certain parts of the inner city and it is linked exclusively with certain social groups and economic processes. Haase and Rink (2015) argue that gentrification and reurbanisation represent two distinct approaches for explaining inner-city transformation, and point to the displacement of former population groups as a major consequence of gentrification. Similarly Grabkowska, who compares gentrification and reurbanisation using the case of Gdańsk, claims that the reurbanisation approach "places the emphasis on enriching the social mix instead of regarding the repopulation as invasion of socio-demographically alien groups of outsiders to the inner city" (Grabkowska, 2015: 213). Indeed, there is also a considerable difference in the etymology and initial meaning of gentrification and reurbanisation: while the former term for rural aristocracy (gentry) represented an ironic, negative perception of this phenomenon in London by Marxist critic Ruth Glass (Glass, 1964; Lees, Slater, Wyly, 2007), reurbanisation is a positive phenomenon welcomed by all authors.

But, similar to gentrification, reurbanisation is also changing the socio-demographic situation at a local level. There are some noticeable signs of the transformation of traditional residential patterns and inner city neighbourhoods in Central and Eastern Europe (Steinführer et al., 2010). In Western Europe - for instance, Manchester - we can observe population growth of the inner cities in the $1990 \mathrm{~s}$, despite the fact that other similar cities stagnated from a demographic point of view (DETR, 2000; Colomb, 2007). This renewed growth of the populations in core city areas indicated the start of the reurbanisation process, driven by a preference for developing local sectors mainly in the service and knowledge economy, such as banking, media, arts and entertainment
(Lever, 1993; Cheshire, 1995). The residential preferences of population groups are changing as a consequence of changing household structure and the occupational structure of the inhabitants. Various studies show the growing attractiveness of core city areas particularly for middle and upper-middle strata of the population (Todorovic and Wellington, 2000; Tallon and Bromley, 2004).

The impact of reurbanisation is discussed from several different points of view. Demographic and social change is closely linked with transformations in the functional structure of inner cities, the spatial aspects of change are related to urbanisation history in particular settlement contexts, and the practical impact of reurbanisation is directly linked to its applications in planning and policy praxis. These factors are discussed in detail here, but we note also here that architectural and legal aspects of the reurbanisation process are examined in contemporary research (Kühn and Liebmann, 2012).

Demographic and social change is one area of prime interest in the evaluation of residential environments influenced by reurbanisation processes. In terms of population trends, the impact of the 'second demographic transition' resulted in falling birth rates among residents, a growing fragmentation of families, an increase of oneperson households, and changes in residents' life styles (Buzar et al., 2007). According to Fishman (2000) and Watters (2004), the process of reurbanisation includes a return of former urban residents from suburbia and the segmentation of inner city neighbourhoods between various social strata. The reurbanisation process is closely linked with demographic developments and with the composition of urban populations. The transformation of core city areas is to a certain extent a result of changing household structures, general trends in demographic development, changes in life styles, value orientations and the social stratification of inhabitants (Haase et al., 2003).

The development of housing and the functional structure of inner city areas is shaped by socio-demographic changes stemming from changing mobility patterns. Growing differences in subjective expectations of urban housing and urban space utilization are important manifestations of demographic change, and also a result of the increasing individualization of society. New household types, such as DINKies or living-together-dwelling-apart, need a new kind of housing, such as co-housing, sub-leasing, accommodation in lodging houses, etc. The central areas of cities may become areas with high rates of residential fluctuations, although it is rather difficult to support this with relevant research methods because of difficulties in the statistical recording of inner city mobility and assessing its causes (Haase et al., 2003). From a methodological point of view, qualitative research and in-depth approaches are more appropriate to study inner city mobility than ordinary quantitative approaches. In addition, it is necessary to take into account specific measures for the development of cities and their effects on reurbanisation, as well as the long-term objectives of city management (Haase et al., 2003).

The spatial aspect of reurbanisation is decisive, since it provides an understanding of population change in particular residential contexts. According to Butler (2007), a growing number of inhabitants in the inner city are sometimes directly linked with an outflow of inhabitants from suburban areas. For example, migration research in Riga dealt with the return moves of suburban population groups back to the central areas of the city, and identified two main groups 
of migrants (Barber, 2007). Firstly, it is clear that those groups moving into the central urban areas were mostly young people who grew up in suburban areas and now study or work in the city. The central areas of the city are characterised by proximity to jobs, cultural venues, shopping opportunities, and options for entertainment (Barber, 2007). The second group of migrants are older persons moving back to the city because of service need: central urban areas are more hospitable for them due to the better availability and accessibility of social and healthcare services.

The situation in post-socialist countries differs to a large extent from experiences drawn from Western Europe and North America. The initial conditions for reurbanisation reflect previous urbanisation experiences, and the ways that reurbanisation can occur stem directly from current demographic and socio-economic developments. Importantly, CEE countries have witnessed far less urban out-migration and suburban sprawl than their western counterparts in the past 25 years, although the terminology used for the description of different empirical realities in the West and in the East is roughly similar (Ouředníček, 2003; Turok and Mykhnenko, 2007). Many CEE countries also deal with outmigration and overall population decrease, which sets limits for population deconcentration (Šimon and Mikešová, 2014). Additionally, studies of counterurbanisation as a prominent form of residential decentralisation, which are relatively common in the Western context, are rather rare in the post-socialist context (see Šimon, 2014, for an overview). Thus, reurbanisation in the post-socialist context occurs under conditions of demographic change and directly after suburbanisation or the ephemeral counterurbanisation stage. The diversity of the urban trajectories of post-socialist cities, however, should be pointed out - and the exceptional case of East Germany should be acknowledged (Rink et al., 2011).

\section{Reurbanisation as a policy approach}

The impact of reurbanisation in inner city areas depends not only on the intensity of population and housing change but also on policy and development praxis. An important role is played by local and regional authorities, which have high competence in planning. For example, in Switzerland local authorities have launched programs designed to attract new residents to the cities and to promote a compact city model Other important actors include investors and developers who shape the housing market in cities and thus also reurbanisation per se (Rérat, 2012). On the other hand, it could be argued that inner city re-population might occur without specific policy tools. Changing housing prices in the inner city and changing demands by smaller or new types of households can lead to inner city re-development as theories of gentrification suggests (Hyra, 2015).

One important difference can be identified between the three urbanisation processes (urbanisation, suburbanisation, counterurbanisation) and reurbanisation at the policy level, in addition to the physical transformation of central parts of the city itself, which is influenced by reconstructions and refurbishments. A qualitative change in the city environment is also a part of this process. Within urban upgrading, the qualitative change includes an intentional refinement of the quality of life in central city areas, which occurs across various social strata in the population, types of households and generations (Haase et al., 2003). Reurbanisation is understood as the development of a city through increasing density of construction, renewed exploitation of unused areas in the city centre, or the revitalisation of brownfield sites (McIntyre and McKee, 2008). The reurbanisation process demands deeper involvement of local government in town planning, stemming from the increasing popularity of PPP (public private partnerships) projects (Šolks, 2010).

In many ways reurbanisation is not just another stage in the development of a settlement system or even a process shaping metropolitan areas, but rather a policy approach, an urban vision or a town planning policy of many municipal governments dealing with the impacts of demographic change in urban space. An array of economic, social and demographic processes supports city expansion, which is often regarded as a negative tendency in relation to sustainable economic and environmental development (Pichler-Milanovič, Gutry-Korycka, Rink, 2007). Many urban and regional policies seek to favour compact city development in order to prevent urban sprawl and to shift attention towards revitalisation of brownfield sites inside the city (Polanska, 2008). This policy appears in the concept of shrinking cities (Šimon and Mikešová, 2014), but also in practice and in the preparation of planning tools and instruments (Hnilička, 2005; Koucký, 2014).

The reurbanisation process is then understood as a process of the long-term stabilisation of central city areas by retaining existing inhabitants and attempting to attract new residents (Haase et al., 2008). For many European cities with a declining number of inhabitants, the reurbanisation process could be the main route and vision for their future development (Turok and Mykhnenko, 2007). Contemporary research shows that the emergence and the extent of the reurbanisation process depends to a considerable degree on a local set of institutional, socio-economic and infrastructure factors (Haase et al., 2011). For example, Griffiths (1995: 254) describes three models to improve the appearance of the city: the integration model, a cultural model and the promotional model. The promotional model emphasizes the benefits of the physical changes of central city space, and entices people to come to the city for work. The activities proposed in the promotional model include the marketing of office spaces, shops, restaurants and cultural facilities. The cultural model focuses on the importance of cultural facilities, especially of high art in cities and their importance for the future development of the city. Cultural strategies are used especially for revitalising the city centre or renewing the image of old industrial cities, and thus restore the potential of city development. The integration model is oriented towards supporting civic identity, which includes the revitalization of public social life, reviving a sense of belonging to the city (Seo, 2002).

Reurbanisation as a policy approach has the potential to be used in the urban policy agenda at a broader scale in contrast to the related concepts of shrinking cities and gentrification, especially when reurbanisation is defined as a process for the re-population and diversification of inner city areas by various social groups (cf. Buzar et al., 2007 and Rérat, 2012), without specifying whether such re-population is achieved by in-migration or by natural change. Reurbanisation is presented mainly as a process of demographic change, which is not implicitly connected with population displacement and social conflicts, as in the case of gentrification (Lees, 2000; Kabisch, Haase, Haase, 2010). Such a neutral description of inner city change might conceal social and political conflicts over urban space.

Reurbanisation is also presented as a positive approach to urban population change applicable in growing, stagnating or shrinking cities. In contrast, the concept of shrinking cities 
is mostly negatively perceived, reluctantly acknowledged and, exceptionally, tackled in urban/public policy. As Bernt et al. (2013) point out: urban shrinkage does not get easily onto the policy agenda. Reurbanisation, on the other hand, is presented as 'an improvement policy' and thus has a positive connotation. At the same time, it might be argued that inner city re-population by migration from outer parts of the city is clearly an opposition to previous urban growth, and thus reurbanisation is minor positive change marking a lowering population significance of the whole metropolitan area. In this article we have reflected on these different perspectives and scales of reurbanisation research, and argued for a broader and more refined understanding of reurbanisation grounded in local population developments in metropolitan regions.

\section{Discussion}

\subsection{Implications for post-socialist urban research}

Particular developmental stages of SUD theory (urbanisation - suburbanisation - counterurbanisation reurbanisation) have been demonstrated as the background for a discussion of urban development in the context of CEE countries. A certain kind of periodicity is revealed for the example of settlement development in the former Czechoslovakia and in the current Czech Republic.

The classic stage of urbanisation, i.e. a distinct concentration of population into cities, took place in Czechoslovakia, particularly in the period of industrialisation. Targeted urbanisation strategies were common for the socialist period. Within this framework, centres of local, district and regional importance were established and supported by state redistributive mechanisms. This centralized settlement system subsequently influenced the dominant streams of migration (Musil, 1977; Hampl and Kühnl, 1993). Growth occurred primarily in selected settlement centres and industrial cities (Matoušek, 1966), however, while some comparatively attractive and easily accessible hinterlands of large cities exhibited a low level of population growth or even population decline. In the centralised settlement policy, there was very little investment in the technical and social infrastructure of suburban villages. This economic disadvantage together with other factors led to the continuous degradation of small settlements and to the outflow of younger people from urban hinterlands (Ouředníček, 2003).

The rise of suburbanisation after 1990 differs from the previous period of concentration and brought a marked change in the shape of large cities and their hinterlands, particularly since the second half of the 1990s (Ouředníček, Špačková, Novák, 2013). Today, suburbanisation is frequently described in media discourse as a negative process of selective migration to small settlements with a low level of services and with a lack of social and technical infrastructure. Many experts anticipate (Hnilička, 2005; Kopečná and Špačková, 2012) that the not-so-well planned migration to suburbs will eventually lead to a gradual return of at least some inhabitants back to the cities (i.e. reurbanisation): already confirmed in the case of the former Eastern Germany (Kabisch, Haase, Haase, 2010; Holm, Marcińczak, Ogrodowczyk, 2015).
The economic downturn, combined with increasing housing prices, created pressures to relocate for the economically weaker population of large industrial cities in East European countries at the beginning of 1990 s, and the discussion of counterurbanisation emerged (Dandolova, 2003; Leetmaa, Tammaru, Anniste, 2009). Economic pressures led to a return of a certain part of the urban population to genuinely rural areas, where housing was less expensive and family and subsistence networks were more available (Ladányi and Szelényi, 1998). Similar trends re-appear in some poorer East European countries as a consequence of the economic crisis in $2008^{2}$. A significant part of such residential decentralisation was driven by the economic unsustainability of urban life for individuals, and migration to rural areas was driven by subsistence reasons. In the Czech Republic, there has also been a certain revival of migration activity outside metropolitan suburban areas since the early 2000s (Ouředníček, Špačková, Feřtrová, 2011). Counterurbanisation, however, has not produced a high absolute population growth in rural areas and it can rather be seen as an alternative migration movement (Šimon, 2014), driven mostly by quality of life and lifestyle motivations. Contemporary counterurbanisation differs in volume and pace from urbanisation and suburbanisation (Ouředníček, 2000). Nonetheless, research on counterurbanisation can contribute to a better understanding of the effects of counterurbanites on local rural environments, especially when differences in migration patterns and its underlying factors between CEE countries are large ${ }^{3}$.

In comparison with urbanisation, suburbanisation and counterurbanisation, reurbanisation has been relatively little studied in the Czech context until recently (Rumpel and Slach, 2012). Reurbanisation as a process has not as yet reached a high level of intensity in the Czech Republic. As noted by Čermák, Hampl and Müller (2009), counterurbanisation and reurbanisation will not cause major changes in the spatial patterns and organisation of the settlement system. On the other hand, these processes will definitely transform local social structures in individual parts of the metropolitan areas.

The importance of reurbanisation can be seen from the spatial (i.e. geographical) perspective, as a process which has source and target destinations. Firstly, the quality of the residential environment of the inner parts of the central city (target localities) of metropolitan areas is decisive. Its potential for redevelopment can be advanced due to the support for inner-city regeneration by the local governments. This part of the process, however, has been widely discussedand it does not create the core of our research program.

Secondly, the changing life-cycle structure of households in suburban areas (with the first generation of emptynesters) gradually provides a source of potential migration back to the inner cities of Prague and other Czech cities (Ouředníček, Špačková, Novák, 2013). This part of the reurbanisation process, which is focused on the stability of the demographic composition of suburbs (as source localities of reurbanisation), is much more important for our research, which deals mainly with suburban development (Ouředníček, 2003, 2007). We argue that the housing

${ }^{2}$ EAST Workshop - 'Depopulation of Rural Areas in Central and Eastern Europe: Causes, consequences and solutions', Görlitz, Germany, 11-13 June 2015, organised by The Oxford Institute of Population Ageing.

${ }^{3}$ For a more detailed evaluation of counterurbanisation in the post-socialist context see Martin Šimon (Šimon and Ouředníček, 2010; Šimon, 2011, 2014). 
preferences of selected groups of suburbanites to move back to the city have the potential to shape suburban-to-urban migration. Among them, the second-generation (adolescents and grown-up children) from the early suburbanisation of the middle 1990s will reach the age of high migration intensity and will shape current population development in older suburban localities. We can ask whether the second generation of suburbanites has different migration housing preferences compared to their parents - and will then stay in the suburbs or move back to the city? As Kopečná and Špačková have confirmed, temporary suburbanites, who escaped the city especially to apartment blocks, seem to be another potential group of reurbanisation migrants, which has less residential stability than households of family houses with their tendencies to out-migrate (Kopečná and Špačková, 2012)

\subsection{Operationalisation of reurbanisation for the post-socialist context}

As the preceding sections illustrate, the reurbanisation process represents an important mechanism of local social change shaping residential environments in inner cities. In the post-socialist condition with its relatively short period of suburbanisation and the population decline of the inner cities, a back-to-the-city migration is expected to occur due to the generational shift of suburban inhabitants (Hnilička, 2005; Ouředníček, Špačková, Novák, 2013). Therefore our working definition (operationalisation) of reurbanisation is based on migration flows ${ }^{4}$ - as a process of return of residents from suburban areas back to the city (see Tab. 1). Our definition of the reurbanisation process is related to the local context rather than to the settlement system per se. On the other hand, the process is similar to other urbanisation processes, and reurbanisation cannot be understood purely in terms of the size and directions of migration flows. It is also necessary to consider contextual and compositional characteristics of this flow: for example, to consider what kind of inhabitants tend to move from suburban areas (back) to the city ${ }^{5}$. It is important, if they are (i) mostly former villagers born in the original builtup area (actually representing the urbanisation process of moving from country to city: see Table 1); (ii) the grownup children of the first generation of suburbanites; or (iii) those (suburbanites) who have moved out of the city in the course of the last two decades (reurbanisation - back to the city). These three groups will certainly have a different composition, as well as distinct reasons for migration, which is decisive for both the source and target areas of metropolitan regions and which is expressed also by social links to inhabitants in both source and target areas.
Consequently, in comparison with all reurbanisation studies which deal with the impacts on inner city neighbourhoods, we would like to focus also on the source destinations of reurbanisation. Currently, the adaptation of new inhabitants in new suburban environments, the tension between their existing life styles, social networks and the localisation of life settings, are under research scrutiny (Špačková and Ouředníček, 2012). This approach to reurbanisation leads to the establishment of a tailormade methodology for the research of residential mobility, focused on tracing fluctuations or stability and satisfaction with housing in various forms of suburban dwelling, which is important for predictions of the future development of suburban neighbourhoods (Kopečná and Špačková, 2012; Ouředníček, Špačková, Novák, 2013).

The definition of urbanisation processes based on migration streams and the empirical experiences from postsocialist cities enable us to update the earlier discussions and to distinguish between reurbanisation and gentrification from a geographical perspective. Firstly, one considerable difference can be seen in target localities of both processes within the city. In accordance with the opinion of Ogden and Hall (2000), it could be said that reurbanisation tendencies are not simply counter-streams of existing migration flows and they are not limited to processes of gentrification or inner city renewal. According to van den Berg et al. (1982), reurbanisation is not primarily embedded in deteriorating parts of the inner city but rather is measured as an increase of the number of inhabitants in the whole core city. In a post-socialist context, another important target area in this respect - besides the inner parts of the city - could be housing estates, which are now serving as starting accommodation for young families or students (Temelová et al., 2011), and are certainly more affordable for these households than inner city neighbourhoods.

A second difference between gentrification and reurbanisation in the post-socialist context relates to the source localities of both processes. It is noteworthy that many scholars of gentrification and reurbanisation describe well their social, economic and demographic structure, but only rarely have they investigated the "from where" both gentrifiers or reurbanites come (for comparison: see the issue of Geografie [2015, No. 2] focused on gentrification in CEE-countries). The character of a previous residence, however, should be at least one of the important factors in which the behaviours of new incomers to the city can differ. While in post-socialist cities gentrification is linked particularly with yuppies and foreigners (Sýkora, 2005), the newcomers from suburbia (reurbanisation) can be completely different in both demographic and socio-

\begin{tabular}{|c|c|c|c|c|}
\hline \multirow{2}{*}{\multicolumn{2}{|c|}{ Type of settlement }} & \multicolumn{3}{|c|}{ Destination (target) of migration } \\
\hline & & Urban & Suburban & Rural \\
\hline \multirow{3}{*}{$\begin{array}{l}\text { Source of } \\
\text { migration }\end{array}$} & Urban & Intra and inter-city migration & Suburbanisation & Counterurbanisation \\
\hline & Suburban & Urbanisation or REURBANISATION & Tangential migration (intra-metropolitan) & Counterurbanisation \\
\hline & Rural & Urbanisation or REURBANISATION & Urbanisation & Rural migration \\
\hline
\end{tabular}

Tab. 1: Source-destination matrix of migration and the definition of reurbanisation

\footnotetext{
${ }^{4}$ It seems that the most suitable tool for the recording of urbanisation processes is the analysis of migration flows (Sjöberg and Tammaru, 1999, Ott, 2000)

5 Theoretically, we could discuss also a return back to the city for the case of counterurbanites. At present, we cannot describe such tendencies in the Czech settlement system, since exact assessments cannot be made due to the lack of relevant data.
} 
economic terms. To reveal emerging migration trends in contemporary suburbia is one of the important research targets of urban geography in post-socialist countries. The intensity and structure of reurbanisation can have a considerable influence on the future development of suburban localities, as well as of cities.

\section{Conclusions}

This contribution to the research literature articulates an effort to clarify the theoretical concept of reurbanisation and its application in research on the socio-spatial differentiation of cities in the Czech Republic, with possible consequences for cities in post-socialist countries in general. The first conclusion is that approaches to the study of reurbanisation should focus on 'process' - from both of the competing perspectives: as an urbanisation process or stage of urban system development, and at the same time as a micro-regional process changing selected parts of metropolitan regions (e.g. suburbs). Both of these perspectives provide valuable insights into population redistribution and residential change in European cities, as they enable evaluations from different geographical scales. Consequently, we perceive reurbanisation as a process changing local social environments and serving often as a policy for positive changes within the inner cities.

Secondly, the elaboration of diverse approaches and conceptualisations of reurbanisation gathered for the purpose of this paper, has contributed to a deeper understanding of the reurbanisation process, but has also demonstrated the enormous "flexibility" and poor clarity of the concept in its academic usage. We have tried to distinguish the most commonly-used terms - gentrification and reurbanisation and to identify the advantages of a clear distinction between these two processes in urban research.

Thirdly, a definition of reurbanisation stemming from the demands of empirical work in the Czech Republic and within the framework of post-socialist (sub)urban research, was elaborated. We define reurbanisation as a process of the return of residents from suburban areas back to the city. The return migration of suburban residents back to the city is an indisputably interesting question in both scientific and media discourse today. The demands for a clear definition of reurbanisation and clarity in its delimitation in relation to other processes changing the urban environment are crucial for the formation of cumulative knowledge. Methodological accuracy and definitional purification (Halfacree, 2001) in researching urbanisation processes should be one of the crucial elements in efforts to improve the explanatory and predictive functions of theoretical concepts in urban geography.

Fourth and finally, although trajectories of inner city decline or reurbanisation are common for many European cities, the research agenda is rather different in postsocialist cities. The relatively short period of residential decentralisation and related population decreases in many cities is to be confronted with profound demographic changes, namely population ageing, changing household structure, and population decrease (Hoff, 2011; Šimon and Mikešová, 2014). The connections between suburbanisation and reurbanisation could be one of the prominent research topics in post-socialist countries. The attention of this kind of research should be paid not only to target localities (inner cities, as well as socialist housing estates) but also to places and neighbourhoods from where people migrate back to the city.

\section{Acknowledgement}

This article was supported by the Czech Science Foundation project GA14-00393S: "Dynamics of social environment and spatial mobility in metropolitan regions of the Czech Republic", and the Grant Agency of Charles University, project B-GEO 878913: "Residential mobility of the population of metropolitan areas in the Czech Republic with an emphasis on the Prague Metropolitan Region".

\section{References:}

ALLEN, C., BLANDY S. (2004): The future of city centre living: implications for urban policy. Centre for Regional Economic and Social Research, Sheffield Hallam University.

ATKINSON, R. (2003): Introduction: misunderstood saviour or vengeful wrecker? The many meanings and problems of gentrification. Urban Studies, 40(12): 2343-2350.

BARBER, A. (2007): Planning for sustainable reurbanisation: policy challenges and city centre housing in Birmingham. Town Planning Review, 78(2): 179-202.

BARON, M., OCHOJSKI, A., POLKO, A., WARZECHA, K., ŠIMON, M. (2014): Economics and Strategic Management of Local Public Services in Central Europe: Towards multidisciplinary analysis of infrastructure and service costs. Prague: Institute of Sociology, Academy of Sciences of the Czech Republic.

BERNT, M. (2009): Partnerships for demolition: The governance of urban renewal in East Germany's shrinking cities. International Journal of Urban and Regional Research, 33(3): 754-769.

BIJAK, J., KUPISZEWSKA, D., KUPISZEWSKI, M. (2008): Replacement migration revisited: Simulations of the effects of selected population and labour market strategies for the aging Europe, 2002-2052. Population Research and Policy Review, 27(3): 321-342.

BORGEGÅRD, L. E., MURDIE, R. (1993): Socio-demographic impacts of economic restructuring on Stockholm's inner city. Tijdschrift voor Economische en Sociale Geografie, 84(4): 269-280.

BOTEV, N. (2012): Population ageing in Central and Eastern Europe and its demographic and social context. European Journal of Ageing, 9(1): 69-79.

BRIDGE, G. (2006): It's not just a question of taste: gentrification, the neighbourhood, and cultural capital. Environment and Planning A, 38(10): 1965-1978.

BUTLER, T. (2007): Re-urbanizing London Docklands: Gentrification, Suburbanization or New Urbanism? International Journal of Urban and Regional Research, 31(4): 759-781.

BUZAR, S., OGDEN, P., HALL, R., HAASE, A., KABISCH, S., STEINFÜHRER, A. (2007): Splintering urban populations: emergent landscapes of reurbanisation in four European cities. Urban Studies, 44(4): 651-677.

CASSIERS, T., KESTELOOT, C. (2012): Socio-spatial inequalities and social cohesion in European cities. Urban Studies, 49(9): 1909-1924.

CHAMPION, T. (2001): Urbanization, Suburbanization, Counterurbanization and Reurbanization. In: Paddison, R. [ed.]: Handbook of Urban Studies (pp. 143-161). London, SAGE Publication. 
CHESHIRE, P. (1995): A new phase of urban development in Western Europe? Evidence for the 1980s. Urban Studies, 32(7): 1045-1063.

CHESHIRE, P., HAY, D. G. (1989): Urban Problems in Western Europe: an economic analysis. Unwin Hyman, London.

COLOMB, C. (2007): Unpacking new labour's 'Urban Renaissance' agenda: Towards a socially sustainable reurbanization of British cities? Planning Practice \& Research, 22(1): 1-24.

ČERMÁK, Z., HAMPL, M., MÜLLER, J. (2009): Současné tendence vývoje obyvatelstva metropolitních areálů v Česku: dochází k významnému obratu? Geografie, 114(1): 37-51.

DANDOLOVA, I. (2003): Deurbanisation in Bulgaria: Challenges of transition and sustainable development. In: Eckardt, F., Hassenpflug, D. [eds.]: Consumption and the post-industrial city (pp. 127-140). Frankfurt/Main, Peter Lang.

DEMIFER - Demographic and Migratory Flows Affecting European Regions and Cities, ESPON 2013 project.

DEPARTMENT OF THE ENVIRONMENT, TRANSPORT AND THE REGIONS (DETR) (2000): Our Towns and Cities: The Future. Delivering an Urban Renaissance, White Paper presented to Parliament by the Deputy Prime Minister and Secretary of State for the Environment, Transport and the Regions by Command of Her Majesty. London: HMSO [online]. [cit. 20. 10. 2013]. Available at: http://www.odpm.gov.uk/index.asp?idL'1127167

FISHMAN, R. (2000): The American metropolis at century's end: Past and future influences. Housing Policy Debate, 11(1): 199-213.

GERŐHÁZI, É., HEGEDÜS, J., SZEMZÖ, H., TOSICS, I., TOMAY, K., GERE, L. (2011): The impact of European demographic trends on regional and urban development. Synthesis Report (Hungarian Presidency of the Council of the European Union), Budapest.

GLASS, R. (1964): London: Aspects of Change. MacKibbon and Kee, Centre for Urban Studies, London.

GLATTER, J., SIEDHOFF, M. (2008): Reurbanisation: Inflationary Use of an Insufficiently Defined Term? Comments on the Definition of a Key Concept of Urban Geography, with Selected Findings for the City of Dresden. Die Erde, 139(4): 289-308.

GO, F., GRIBLING, M., VAN DUEREN DE HOLLANDER, M. (2000). Rotterdam 2001: Creating More Cultural Capital than it Costs. International Journal of Arts Management, 2(2): 26-39.

GRABKOWSKA, M. (2015): Between gentrification and reurbanisation: The participatory dimension of bottom-up regeneration in Gdańsk, Poland. Geografie, 120(2): $210-225$.

GRIFFITHS, R. (1995): The politics of cultural policy in urban regeneration strategies. Policy and Politics, 21(1): 39-46.

HAASE, A., STEINFÜHRER, A., KABISH, S. (2003): Understanding, Hypotheses and Key Indicators of Reurbanisation with Reference to Demographic Change. Compilation based on the contributions of the project consortium. EU financed Project „Re Urban Mobil Mobilising Reurbanisation on Condition of Demographic
Change“, 6th Framework Program of the EU, Key action City of Tomorrow and Cultural Heritage, pp. 44 [online]. [cit. 20.6. 2015] Available at: http://www.re-urban.com/ downloads/final_paper72.pdf

HAASE, D., HAASE, A., KABISH, S., BISCHOFF, P. (2008): Guidelines for the "Perfect Inner City". Discussing the Appropriateness of Monitoring Approaches for Reurbanization. European Planning Studies, 16(8): 1075-1100.

HAASE,A., KABISH,S.,STEINFÜHRER,A.,BOUZAROVSKI, S., HALL, R., OGDEN, P. (2010): Emergent spaces of reurbanisation: exploring the demographic dimension of inner-city residential change in a European setting. Population, Space and Place, 16(5): 443-463.

HAASE, A., STEINFÜHRER, A., KABISCH, S., GROSSMANN, K., HALL, R. [eds.] (2011): Residential Change and Demographic Challenge. The Inner City of East Central Europe in the $21^{\text {st }}$ Century. Surrey/ Burlington, Ashgate.

HAASE, A., RINK, D. (2015): Inner-city transformation between reurbanisation and gentrification: Leipzig, eastern Germany. Geografie, 120(2): 226-250.

HALÁS, M., ROUBÍNEK, P., KLADIVO, P. (2012): Urbánní a suburbánní prostor Olomouce: teoretické přístupy, vymezení, typologie. Geografický časopis, 64(4): 289-310.

HALFACREE, K. (2001): Constructing the Object: Taxonomic Practices, Counterurbanisation and Positioning Marginal Rural Settlement. International Journal of Population Geography, 7(5): 395-411.

HALL, P., HAY, D. (1980): Growth Centres in the European Urban System. London, Heinemann Educational.

HALL, R., OGDEN, P. E. (1992): The social structure of new migrants to London Docklands: recent evidence from Wapping. The London Journal, 17(2): 153-169.

HAMPL, M., KÜHNL, K. (1993): Migratory trends in former Czechoslovakia. Acta Universitatis Carolinae Geographica, 28(1): 53-71.

HNILIČKA, P. (2005): Sídelní kaše: otázky k suburbánní výstavbě kolonií rodinných domů. Brno, Era.

HOFF, A. [ed.] (2011): Population Ageing in Central and Eastern Europe. Societal and Policy Implications. Farnham, UK \& Burlington, VT, USA, Ashgate.

HOLM, A., MARCIŃCZAK, S., OGRODOWCZYK, A. (2015): New-build gentrification in the post-socialist city: Łodź and Leipzig two decades after socialism. Geografie, 120(2): 164-187.

HUTTON, T.A. (2004): The new economy of the inner city. Cities, 21(2): 89-108.

HYRA， D. (2015): The back-to-the-city movement: Neighbourhood redevelopment and processes of political and cultural displacement. Urban Studies, 52(10): 1753-1773.

ILLERIS, S. (1991): Location of services in a service society. In: Daniels, P.W., Moulaert, F. [eds.]: The changing geography of advanced producer services (pp. 91-109). London, Wiley.

KABISCH, N., HAASE, D., HAASE, A. (2010): Evolving reurbanisation? Spatio-temporal dynamics as exemplified by the East German city of Leipzig. Urban Studies, 47(5): 967-990. 
KOPEČNÁ, M., ŠPAČKOVÁ, P. (2012): Rezidenční stabilita obyvatel pražského zázemí: př́ípadová studie obce Říčany u Prahy. In: Ouředníček, M., Temelová, J. [eds.]: Sociální proměny pražských čtvrtí (pp. 206-228). Praha, Academia.

KOUCKÝ, R. (2014): Územní plán sídelního útvaru hl. m. Prahy [online]. [cit. 20.6. 2015]. Available at: http://www. uppraha.cz/clanek/53/platny-uzemni-plan-hlavnihomesta-prahy

KÜHN, M., LIEBMANN, H. (2012): Urban Regeneration Strategies of Shrinking Cities in Eastern Germany. Die Erde, 143(1-2): 135-152.

LADÁNYI, J., SZELÉNYI, I. (1998): Class, ethnicity and urban restructuring in post-communist Hungary. In: Enyedi, Gy. [ed.]: Social Change and Urban Restructuring in Central Europe (pp. 67-86). Budapest, Akadémiai Kiadó.

LAIS, K., PENKER, M. (2012): Local Government Budgets Stressed by Population Decline? - An Analysis of Residual Costs for the Local Communities of Styria in Austria. Lex Localis, 10(1): 111-128.

LEES, L. (2000): A reappraisal of gentrification: towards a 'geography of gentrification'. Progress in Human Geography, 24(3): 389-408.

LEES, L., SLATER, T., WYLY, E. (2007): Gentrification. New York, Routledge.

LEETMAA, K., TAMMARU, T., ANNISTE, K. (2009): From Priority-Led To Market-Led Suburbanisation in a PostCommunist Metropolis. Tijdschrift voor Economische en Sociale Geografie, 100(4): 436-453.

LESTHAEGHE, R., WILLEMS, P. (1999): Is Low Fertility a Temporary Phenomenon in the European Union? Population and Development Review, 25(2): 211-228.

LEVER, W. (1993): Re-urbanisation - the policy implications. Urban Studies, 30(2): 267-284.

MATOUŠEK, V. (1966): Soudobé tendence rovnoměrnosti a koncentrace osídlení v kapitalistických a socialistických zemích (II. část), 2(6): 792-802.

MCINTYRE Z., MCKEE, K. (2008): Governance and sustainability in Glasgow: connecting symbolic capital and housing consumption to regeneration. Area, 40(4): 481-490.

MILLARD-BALL, A. (2002): Gentrification in a Residential Mobility Framework: Social Change, Tenure Change and Chains of Moves in Stockholm. Housing Studies, 17(6): 833-856.

MUSIL, J. (1977): Urbanizace v socialistických zemích. Praha, Svoboda.

MUSIL, J. (1993): Changing urban systems in postcommunist societies in Central Europe: analysis and prediction. Urban Studies, 30(6): 899-905.

MUSIL, J. (2005): Why Socialist and Post-Socialist Cities Are Important for Forward Looking Urban Studies. Unpublished conference paper presented at the conference 'Urban Science Forward Look', Helsinki, 26-28 May 2005.

OGDEN, P. E., HALL, R. (2000): Households, reurbanisation and the rise of living alone in the principal French cities 1975-1990. Urban Studies, 37(2): 367-390.
OTT, T. (2001): From Concentration to De-concentration Migration Patterns in the Post-socialist City. Cities, 18(6): 403-412.

OUŘEDNÍČEK, M. (2000): Teorie stádií vývoje měst a diferenciální urbanizace. Geografie, 105(4): 361-369.

OUŘEDNÍČEK, M. (2003): Suburbanizace Prahy. Sociologický časopis, 39(2): 235-253.

OUŘEDNÍČEK, M., ŠPAČKOVÁ, P., FEŘTROVÁ, M. (2011): Změny sociálního prostředí a kvality života $\mathrm{v}$ depopulačních regionech České republiky. Sociologický časopis/Czech Sociological Review, 47(4): 777-803.

OUŘEDNÍČEK, M., ŠPAČKOVÁ, P., NOVÁK, J. [eds.] (2013): Sub Urbs: Krajina, sídla a lidé. Praha, Academia.

PIRO, R., GANSER, R. [eds.] (2012): Parallel Patterns of Shrinking Cities and Urban Growth: Spatial Planning for Sustainable Development of City Regions and Rural Areas. Farnham, Ashgate.

PICHLER-MILANOVIČ， N., GUTRY-KORYCKA， M., RINK, D. (2007): Sprawl in the post-socialist city: the changing economic and institutional context of central and eastern European cities. In: Urban Sprawl in Europe: Landscapes, land-use change and policy (pp. 102-135).

POLANSKA, D. (2008): Decline and revitalization in postcommunist urban context: A case of the Polish city-Gdańsk. Communist and Post-Communist Studies, 41(3): 359-374.

RÉRAT, P. (2012): The New Demographic growth of Cities: The Case of Reurbanisation in Switzerland, Urban Studies, 49(5): 1107-1125.

RINK, D., HAASE, A., BERNT, M., ARNDT, T., LUDWIG, J. (2011): Urban shrinkage in Leipzig, Germany: Research report, EU 7 FP Project Shrink Smart, Working Paper WP2. UFZ-Bericht, Helmholtz-Zentrum für Umweltforschung [online]. [cit. 28.3.2015]. Available at: http://www.econstor.eu/handle/10419/57866

RUMPEL, P., SLACH, O. (2012): Je Ostrava „smrštujícím se městem"? Sociologický časopis/Czech Sociological Review, 48(5): 859-878.

SEO, J. K. (2002): Re-urbanisation in Regenerated Areas of Manchester and Glasgow, New Residents and Problems of Sustainability, Cities, 19(2): 113-121.

SJÖBERG, Ö., TAMMARU, T. (1999): Transitional Statistics: Internal Migration and Urban Growth in Post-Soviet Estonia. Europe-Asia Studies, 51(5): 821-842.

SMITH, N. (1996): The New Urban Frontier: Gentrification and the revanchist city. Routledge, New York.

STEINFÜHRER, A., BIERZYŃSKI, A., GROSSMANN, K., HAASE, A., KABISH, S., KLUSÁČEK, P. (2010): Population decline in Polish and Czech cities during postsocialism? Looking behind the official statistics, Urban Studies, 47(11): 2325-2346.

SÝKORA, L. (2005): Gentrification in post-communist cities. In: Atkinson, R., Bridge, G. (eds.): Gentrification in a Global Context (pp. 91-105). London, Routledge.

SZABÓ, T., SZABÓ, B., KOVÁCS, Z. (2014): Polycentric urban development in post-socialist context: the case of the Budapest Metropolitan Region. Hungarian Geographical Bulletin, 63(3): 287-301.

SZELÉNYI, I. (1984): Cities and the problem of the transition: introduction and rejoinder. International Journal of Urban and Regional Research, 8(1): 1-12. 
ŠIMON, M. (2011): Kontraurbanizace: chaotický koncept? Geografie, 116(3): 231-255.

ŠIMON, M. (2014): Exploring Counterurbanisation in a PostSocialist Context: Case of the Czech Republic. Sociologia Ruralis, 54(2): 117-142.

ŠIMON, M., MIKEŠOVÁ, R. (2014): Population Development and Policy in Shrinking Regions: the Case of Central Europe. Prague: Institute of Sociology, Academy of Sciences of the Czech Republic.

ŠIMON, M., OUŘEDNÍČEK, M. (2010): Migrace na venkov a kontraurbanizace: Přehled konceptů a diskuze jejich relevance pro výzkum v Česku. In: Geografie pro život ve 21. století (pp. 738-743). Ostrava.

ŠOLKS, G. (2010): Reurbanizácijus processi Rígá. Processes of reurbanization in Ríga. Latvias univerzsitátes Raksti, Zemes un Vides zinátnes (pp. 156-163).

ŠPAČKOVÁ, P., OUŘEDNÍČEK, M. (2012): Spinning the Web: New Social Contacts of Prague's Suburbanites. Cities, 29(5): 341-349.

TALLON, A. R., BROMLEY, R. D. F. (2004): Exploring the attractions of city centre living: Evidence and policy implications in British cities. Geoforum, 35(6): 771-787.
TEMELOVÁ, J., NOVÁK, J., OUŘEDNÍČEK, M., PULDOVÁ, P. (2011): Housing Estates after Socialism: Various Trajectories and Inner Differentiation. Urban Studies, 48(9): 1811-1834.

TODOROVIC, J., WELLINGTON, S. (2000): Living in Urban England: Attitudes and Aspirations. London, Department of the Environment, Transport and the Regions.

TUROK, I., MYKHNENKO, V. (2007): The trajectories of European cities, 1960-2005. Cities, 24(3): 165-182.

URBED, MORI SOCIAL RESEARCH \& THE UNIVERSITY OF BRISTOL (1999): But Would You Live There? Shaping Attitudes to Urban Living. London, HMSO.

VAN DEN BERG, L., DREWET, R., KLAASEN, L. H., ROSSI, A., VIJVERBERG, C. H. T. (1982): A Study of Growth and Decline. Urban Europe, Vol. 1. Oxford, Pergamon Press.

WATTERS, I. (2004): Urban Tribes: Are Friends the New Family? London, Bloomsbury.

Initial submission 28 July 2014, final acceptance 30 November 2015

Please cite this article as:

OUŘEDNÍČEK, M., ŠIMON, M., KOPEČNÁ, M. (2015): The reurbanisation concept and its utility for contemporary research on postsocialist cities: The case of the Czech Republic. Moravian Geographical Reports, 23(4): 26-35. DOI: 10.1515/mgr-2015-0022. 